\title{
Investigation of the damp-heating processing of multilayer fabric
}

\author{
DOI: $10.35530 / 1 T .071 .06 .1788$
}

\section{ABSTRACT - REZUMAT}

\section{Investigation of the damp-heating processing of multilayer fabric}

With the global industrial technology development, technological processes in the textile and clothing industry are constantly evolving. These rapid rates of development necessitate the need for continuous research and analysis to establish optimal operating modes for various technological processes. The damp-heating processing/DHP is one of the main technological processes in the sewing industry. The quality of the sewing article depends to a large extent on the quality of the performance of operations in the damp-heating processing. The wide variety of textile materials, each with different composition, structure and properties, is a prerequisite for conducting extensive research to refine manageable factors of the DHP process. In recent years, textile materials with an increasingly complex structure and multicomponent composition have become increasingly important. Of particular interest are the so-called double woven fabrics. Therefore, the subject of this study is the damp-heating processing of an innovative textile fabric tissue - a multilayer weave type "double cloth". One of the main controllable factors of the damp-heating processing is the amount of moisture introduced into the processed textile materials. The aim of this paper is to determine the limit values for the amount of steam used in the damp-heating processing of a tissue - a multilayer weave type "double cloth".

Keywords: sewing companies, amount of steam, limit values

\section{Investigarea prelucrării prin încălzire umedă a țesăturilor multistrat}

Odată cu dezvoltarea tehnologiei industriale globale, procesele tehnologice din industria textilă și de îmbrăcăminte sunt în continuă evoluție. Această dezvoltare rapidă necesită cercetare și analiză continuă pentru a stabili modurile de operare optime pentru diferite procese tehnologice. Prelucrarea prin încălzire umedă/DHP reprezintă unul dintre principalele procese tehnologice din industria de îmbrăcăminte. Calitatea articolului asamblat depinde într-o mare măsură de calitatea performanței operațiilor din prelucrarea prin încălzire umedă. Varietatea largă de materiale textile, fiecare cu compoziție, structură și proprietăți diferite, este o condiție prealabilă pentru desfășurarea unor cercetări ample pentru a optimiza parametrii controlabili ai procesului DHP. În ultimii ani, materialele textile cu o structură din ce în ce mai complexă și o compoziție multi-componentă au devenit din ce în ce mai importante. Un interes deosebit îl reprezintă așa-numitele țesături duble. Prin urmare, subiectul acestui studiu este prelucrarea prin încălzire umedă a țesăturilor textile inovatoare - o țesătură multistrat tip „țesătură dublă”. Unul dintre principalii parametri controlabili ai prelucrării prin încălzire umedă este cantitatea de umiditate introdusă în materialele textile prelucrate. Scopul acestei lucrări este de a determina valorile limită pentru cantitatea de abur utilizată în prelucrarea prin încălzire umedă a unei țesături multistrat tip „,̦esătură dublă”.

Cuvinte-cheie: companii din industria de îmbrăcăminte, cantitate de abur, valori limită

\section{INTRODUCTION}

Damp-heating processing is one of the main technological processes in the sewing industry. The quality of the sewing article depends to a large extent on the quality of the performance of operations in the dampheating processing.

From the literature review, it can be summarized that some relationships between individual parameters of this process have been investigated [1-5]. These studies have been the subject of work by a number of scientific experts and elite world-renowned sewing companies. However, many of the results from these studies are confidential or commercial information. The influence of some factors on the efficiency of the damp-heating processing has been investigated. For example, a mathematical model of heat and mass exchange in a textile bundle where moisture permeability is present has been developed [1]. In it the problem of heat transport in a bundle of textile material is considered, but the effect of pressure is not taken into account.

Furthermore, for various types of textile materials, the complex influence of manageable factors that optimally satisfy the quality and productivity criteria is not sufficiently clarified. The subject of scientific research was the damp-heating processing of textile materials of different composition - cotton and cotton type [2], chemical textile materials [3] and others. However, the processes of damp-heating processing with a steam press for textile materials of different structure have not been clearly explained and defined.

The wide variety of textile materials and the emergence of more and more new ones requires continuous experimentation to determine parameters of the damp-heating processing for textile materials of different structure. For example, a tissue - a multilayer weave type "double cloth" have become more and more used in the sewing industry in recent years and this has motivated the present study. 
One of the main controllable factors of the dampheating processing is the amount of moisture introduced into the processed textile materials.

Traditionally, many preliminary experiments are generally performed in scientific works in order to define the limits of the individual controllable factors of the respective technological process, and then they proceed to mathematical modelling and optimization [6-9] of the process.

\section{EXPERIMENTAL WORK}

In light of the foregoing, the aim of this paper is to determine the limit values for the amount of steam used in the damp-heating processing of a tissue - a multilayer weave type "double cloth". This study is essential because it creates the conditions for mathematical modeling of the process for the type of textile material involved.

In addition, the present study proposes that the method for the determination of the parameter limit values "the amount of steam used" be used as a method of operation for the production of large lots as well. This will create conditions for the precise adjustment of the ironing machines in advance, in accordance with the composition and structure of the processed textile materials in large series of clothing.

In connection with these goals, the main task is to study the relationship between:

- the temperature difference measured at different points of processed textile materials;

- the amount of steam introduced in the damp-heating processing.

\section{Conditions to execute the experiment}

The most commonly used wet-heat treatment machines are steam ironing presses. The present studies are carried out with a steam ironing press HR-2A-04 HOFFMAN.

The moisture quantification means is a bolt, spring and piston, by means of which the opening - inlet steam and the outlet - steam of the press are regulated.

Highly effective levels of the steam temperature and the pressure between pressing cushions were determined in preliminary studies. In this study, they are constant values.

The steam temperature is $150^{\circ} \mathrm{C}$.

The pressure between the pressing cushions is $130 \mathrm{kPa}$

\section{Materials}

The textile material studied is a double woven fabric (for winter sports, hunting and tourism) "Hunter'12", produced by "E. Miroglio SA" - Sliven, Bulgaria. Flexible textile product is a fabric of multilayer weave type "double fabric". The considered pattern consists of 2 classical twills $-3 / 1$ twill for the face fabric and 2/1 twill for the reverse fabric. Between the face fabric and the reverse fabric there is an intermediate bonding layer of chemical threads [10,11].

Pure $100 \%$ cotton fibers make the face layer of the fabric and $100 \%$ wool fibers make the reverse layer of the fabric. The intermediate layer is made of chemical fibers - polyamide and viscose $[10,11]$.

This textile material has an extremely complex structure and multicomponent composition. It is relatively new and especially up-to-date as it is multifunctional. It was created and protected by an invention patent at the end of 2016 [11]. In this sense, the results of this research are of particular interest. It is for this reason that the current research is conducted with it.

\section{Methods}

In formulating the conditions and methods for conducting the experiment, the principles of the morphological method for analysis and synthesis of methods are applied [12].

In the technological production of sewing products in actual production, the most commonly used types of seams are analogs of seams given in figure 1.

In the context of the above, two experiments were conducted:

- the first experiment („Experiment I“) - with two number of layers of processed textile materials with analogues of stitches given in figure 1, $a, b$;

- the second experiment („Experiment II“) - with three number of layers of processed textile materials with analogues of seams given in figure 1,c, $d$.

„Experiment I" is conducted for two layers of tissue. "Experiment II" is conducted for three layers of tissue. The method of measuring the temperature of textile materials when steam cushions are closed is an interesting engineering task. In this work, the method of establishing direct contact with the tissue packet studied is used. For this purpose a computer integrated measuring system is used [13]. In this way constant feedback is maintained with processed textile materials.

It is important to keep in mind that each layer of processed textile materials changes its temperature to a different degree. For this reason, it is necessary to monitor the temperature below the top and bottom layers of textile materials. Therefore, the temperature reading method should allow the temperature to be monitored at two points in the tissue packet being processed. The computer-integrated measurement

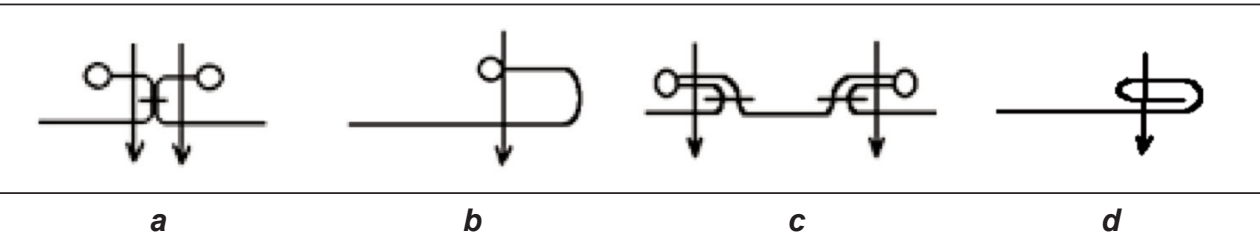

Fig. 1. Laying of textile materials in the course of „Experiment I" and „Experiment II“: $a$ - superimposed connecting seam, with two-way ends; $b$ - end-folded seam with a once-folded end; $c$ - superimposed connecting seam with one-sided ends; $d$ - double-folded end seam 
system [13] provides this capability and is therefore used to carry out experiments in the present work.

The method of accounting for temperature data is given as follows:

- for „Experiment I“, in figure 2, a;

- for „Experiment II“, in figure 2, b.

Temperature data are reported in points 1 and 2 (illustrated in figure 2) of processed textile materials.

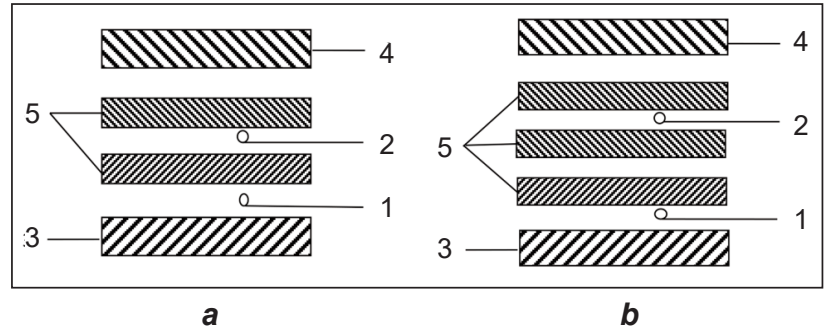

Fig. 2. Method of placement of thermocouples at temperature reading for: $a-$ „Experiment l“; $b$ - „Experiment II“; 1,2 - report points; 3 - bottom cushion of the press; 4 - top cushion of the press 5 - number of layers of the treated textile material

\section{RESULTS AND DISCUSSIONS}

\section{Experimental results}

In this paper, the dependence of $\Delta T\left[{ }^{\circ} \mathrm{C}\right] / H[\mathrm{~mm}]$ is investigated for the specific steam press and textile materials tested, where:

$T_{1}$ - the temperature recorded by the sensor from position 1 (figure 2, a - for „Experiment I“; figure 2, b - for „Experiment II“);

$T_{2}$ - the temperature recorded by the thermocouple from position 2 (figure 2, a - for „Experiment I“; figure 2, $b$ - for „Experiment II“).

$H, \mathrm{~mm}$ - steam quantity according to the position of the adjustment bolt of the ironing machine and

$$
\Delta T=T_{2}-T_{1}
$$

The results of "Experiment I" and "Experiment II" are presented in table 1.

Table 1

\begin{tabular}{|c|c|c|c|c|}
\hline \multicolumn{5}{|c|}{$\begin{array}{l}\text { RESULTS OF CONDUCTED STUDIES FOR } \\
\text { "EXPERIMENT I" AND “EXPERIMENT II" }\end{array}$} \\
\hline Study №, j & $\begin{array}{r}\text { Tem } \\
\text { differer }\end{array}$ & $\begin{array}{l}\text { ture } \\
\Delta T_{1}\left({ }^{\circ} \mathrm{C}\right)\end{array}$ & $\begin{array}{r}\text { Tem } \\
\text { differer }\end{array}$ & $\begin{array}{l}\text { ature } \\
\Delta \mathrm{T}_{\|}\left({ }^{\circ} \mathrm{C}\right)\end{array}$ \\
\hline $\begin{array}{l}\text { Variant №, } \\
\text { i, } \mathrm{H} \text { (mm) }\end{array}$ & $\Delta T_{1,1}$ & $\Delta T_{1,2}$ & $\Delta \mathrm{T}_{\|, 1}$ & $\Delta \mathrm{T}_{\|, 2}$ \\
\hline$B_{1}-0$ & 10.5 & 11.5 & 14.0 & 13.0 \\
\hline$B_{2}-1$ & 8.0 & 7.5 & 11.0 & 10.0 \\
\hline $\mathrm{B}_{3}-2$ & 5.5 & 5.0 & 7.5 & 7.0 \\
\hline $\mathrm{B}_{4}-3$ & 3.0 & 2.5 & 4.5 & 4.0 \\
\hline$B_{5}-4$ & 1.5 & 2.0 & 3.0 & 3.5 \\
\hline $\mathrm{B}_{6}-5$ & 1.0 & 1.5 & 2.5 & 2.0 \\
\hline$B_{7}-6$ & 0.5 & 1.0 & 1.5 & 1.0 \\
\hline $\mathrm{B}_{8}-7$ & 1.0 & 0.5 & 0.5 & 1.0 \\
\hline $\mathrm{B}_{9}-8$ & 0.5 & 0.5 & 1.0 & 0.5 \\
\hline $\mathrm{B}_{10}-9$ & 1.0 & 0.5 & 1.0 & 0.5 \\
\hline
\end{tabular}

The number of repeated observations at each point in the experiment was 2 .

\section{Discussion of experimental results}

It is necessary to carry out a process reproducibility check, which is reduced $[14,15]$ to a dispersion perseverance check (by Cochran's C test):

$$
\begin{gathered}
G_{C}=\frac{S_{i \max }^{2}}{\sum_{i=1}^{B} S_{i}^{2}} \\
G_{T}\left\{\begin{array}{l}
f_{1}=m-1 \\
f_{2}=B \\
r=0.05
\end{array}\right\}
\end{gathered}
$$

where $m$ is the number of repeated observations for each variant, $B$ - number of variant, $f_{1}$ and $f_{2}-$ degrees of freedom, $r$ - significance level.

For "Experiment I", the results for the calculated and tabulated value of the Cochran's $C$ test are:

$$
G_{C, I}=0.3333 ; G_{T, I}\left\{\begin{array}{l}
f_{1}=1 \\
f_{2}=10 \\
r=0.05
\end{array}\right\}=0.6020
$$

For "Experiment II", the results for the calculated and tabulated value of the Cochran's $C$ test are:

$$
G_{C, I l}=0.25 ; \quad G_{T, I I}\left\{\begin{array}{l}
f_{1}=1 \\
f_{2}=10 \\
r=0.05
\end{array}\right\}=0.6020
$$

Therefore, the intra-group dispersion (for "Experiment I" and "Experiment II") does not differ statistically and the process is reproducible.

As a result of the experiments conducted, limit values for the factor "amount of steam introduced" (according to the position of the special steam control bolt for this press) can be determined. The minimum value of the amount of steam introduced into processed textile materials is determined by the condition [9] for proper operation of the damp-heating processing. According to this condition, the temperature difference in the thickness of processed textile materials (between point 1 and point 2 of figure 2) should not be greater than $2-4^{\circ} \mathrm{C}$. Therefore, the minimum value of the setting bolt position is $H=3 \mathrm{~mm}$ (for "Experiment I" and "Experiment II").

On the other hand, in table 1 , it can be clearly seen that an increase in $H, m m$ above a certain value does not lead to a decrease in the temperature difference $\Delta T^{\circ} \mathrm{C}$. Therefore, increasing the amount of steam introduced (according to the position of the adjustment bolt $-H, \mathrm{~mm}$ ) above this limit value will not lead to a positive technological effect. Such an increase in $H$, mm will only leads to energy and time over consuming. Therefore, the appropriate maximum value of the position of the adjustment bolt $H, \mathrm{~mm}$ the amount of steam introduced is:

- for "Experiment I" $-H=6 \mathrm{~mm}$;

- for "Experiment II" - $H=7 \mathrm{~mm}$. 


\section{CONCLUSIONS}

In the light of the results obtained, it can be summarized that the present research has an applied scientific character.

From one side, this research creates the conditions to put on a scientific basis a multifactorial engineering problem through the application of a mathematical method.

The amount of steam introduced into textile materials during damp-heating processing (according to the position of the special press adjustment bolt) is one of the main controllable factors of the process. The determination of its limit values for the particular type of textile material (a tissue a multilayer weave type "double cloth" - "Hunter'12", produced by "E. Miroglio
SA" - Sliven, Bulgaria) creates the conditions for planning and conducting a multifactorial experiment. This will allow mathematical modelling and optimization of the damp-heating processing for this type of textile materials.

The applicability of this study is expressed in the presentation of the method that can be used in the production of large batches.

The methodology is expressed in the presentation of the successive stages for the determination of limit values of the parameter "amount of moisture introduced".

This gives the possibility of precise adjusting of ironing machines in the production of large batches.

\section{REFERENCES}

[1] Sharpar, N.M., Osmanov, Z.N., Mathematical Model of Heat and Mass Exchange in Bundle of Textile Material Where Moisture Permeability is Present, In: Fibre Chemistry, 2019, 51, 2, 147-152

[2] Andonova, S., Investigation the influence of the cloth packs area on the temperature changes during the ironing process of cotton details, In: Textile and Clothing, 2006, 1, 17-19

[3] Andonova, S., Capanuk, U., Technological specifications of damp - heating process of chemical textile materials In: Textile and Clothing, 2018, 4, 129-133

[4] Isaev, V., Franz, V., The device, work, adjustment and repair of sewing machines, In: Light Industry, Moscow, 1986

[5] Motejl, V., Machines and equipment in clothing production, In: SNTL, Praha, 1984

[6] Amudjev, I.M., Krumov, K.K., Kuzmanov, T.V., Modelling of the micro hardness obtained in the burnishing process by means of adding rotations around crossing axes, In: Journal Mechanical Engineering and Machine Science, 2011, 13-1, 64-68

[7] Nedyalkov, I., Stefanov, A., Georgiev, G., Modelling and Studying of Cloud Infrastructures, In: International Conference on High Technology for Sustainable Development, HiTech 2018 - Proceedings, Sofia, Bulgaria, 2018, Article number 8566664, 1-4, http://doi:10.1109/HiTech.2018.8566664

[8] Al-Sehemi, A.G., Al-Ghamdi, A.A., Dishovsky, N.T., Malinova, P.A., Atanasov, N.T., Atanasova, G.L., Analysis of the electrical and magnetic properties of elastomeric composites and their applicability in small flexible wearable antennas, In: Materials Research Express, 2017, 4, 7, Article number 076304

[9] Sapundji, F., Popstoilov, M., Optimization algorithms for finding the shortest paths, In: Bulgarian Chemical Communications, 2018, 50, Special Issue-B, 115-120

[10] Rahnev, Iv., Gaetano, R., Isotropy equilibrium of the double woven fabric with cotton face and wool reverse fibrous compositions, In: IOP Conference Series: Materials Science and Engineering, Issues, 2017, http://iopscience. iop.org/volume/1757-899X/254

[11] Rahnev, Iv., Double workwear fabric, Patent for invention №66551/01.11.2016, BG 66551 B1,

[12] Amudjev, I.M., Applying of the morphological method for analysis and synthesis of methods for finishing of external cylindrical surfaces by means of surface plastic deformation, In: Journal of Technical University - Gabrovo, 2007, $34,19-25$

[13] Trifonov, K., Andonova, S., Gebov, V., Computer-integrated system for measuring the temperature during pressing, In: Textile and Clothing, 2005, 11, 18-21

[14] Damyanov, G., Germanova-Krasteva, D., Textile Processes: Quality Control and Design of Experiments, In: Momentum Press, NY, 2012

[15] Germanova-Krasteva, D., Textile Testing and Analysis, In: TU University Press, Sofia, Bulgaria, 2012

Authors:

SNEZHINA ANDONOVA, IVAN AMUDZHEV

South-West University “Neofit Rilski”, Faculty of Engineering, Mechanical engineering and technology, 66 Ivan Michailov st., 2700, Blagoevgrad, Bulgaria

Corresponding author:

SNEZHINA ANDONOVA

e-mail: andonova_sn@abv.bg 